\title{
Pseudomonas aeruginosa associated pulmonary infections and in vitro amplification virulent rhamnolipid (rhIR) gene
}

\author{
Infecções pulmonares associadas a Pseudomonas aeruginosa e gene ramnolipídeo \\ virulento (rhlR) da amplificação in vitro
}

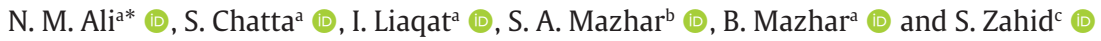 \\ ${ }^{a}$ Microbiology laboratory, Department of Zoology, GCU Lahore, Pakistan \\ 'Fatima Memorial Hospital Lahore, Pakistan \\ cServices Hospital Lahore, Pakistan
}

\begin{abstract}
Background: Pseudomonas aeruginosa is a common opportunistic pathogenic bacterium with the ability to develop a strong communication pathway by quorum sensing system and different virulent factors. Among the various important secretions of $P$. aeruginosa rhamnolipid is important biological detergent, believed to be involved in the development of the biofilm and intercellular communication. It readily dissolves the lung surfactants that are then easily catalyzed by the phospholipases and in this way is involved in the acute pulmonary infection. Objective: research work was designed to investigate virulence and gene associated with virulence in $P$. aeruginosa responsible for pulmonary infections. Methods: In current study polymerase chain reaction (PCR) was used for the detection of the rhlR (rhamnolipid encoding) gene of isolated strains. A number of assays were performed that ensured its virulent behavior. Disc diffusion method was used to check its antibiotic resistance. Isolated strains were resistant to a number of antibiotics applied. Result: It was found that males are more prone to respiratory infections as compared to females. Male members with age of 44-58 and 59-73 are at a higher risk, while females with age of 44-58 are also at a risk of pulmonary infections. Antibiotic resistance was observed by measuring

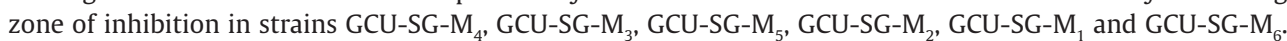
GCU-SG-M $\mathrm{M}_{2}$ was resistant to fluconazole (FLU), clarithromycin (CLR), cefixime (CFM) and Penicillin (P10). No zone of inhibition was observed. But it showed unusual diffused zone around the Ak and MEM antibiotic discs. rhl $R$ gene and 16s rRNA gene were characterized and analyzed. Conclusion: Findings from current study would help in raising awareness about antibiotic resistance of $P$. aeruginosa, and also the sequence of $r h l R$ gene can be used as the diagnostic marker sequence to identify the virulent $r h l R$ gene sequence from the samples when isolated from sputum of Pneumonia patients.
\end{abstract}

Keywords: molecular characterization, risk factors, antibiotics resistance, virulence assays.

\begin{abstract}
Resumo
Antecedentes: Pseudomonas aeruginosa é uma bactéria patogênica oportunista comum, com a capacidade de desenvolver uma forte via de comunicação pelo sistema de detecção de quorum e diferentes fatores virulentos. Entre as várias secreções importantes de P. aeruginosa rhamnolipid, há um importante detergente biológico, que se acredita estar envolvido no desenvolvimento do biofilme e na comunicação intercelular. Dissolve rapidamente os surfactantes pulmonares que são facilmente catalisados pelas fosfolipases e, dessa maneira, estão envolvidos na infecção pulmonar aguda. Objetivo: $O$ trabalho de pesquisa foi desenhado para investigar a virulência e o gene associado à virulência em P. aeruginosa responsável por infecções pulmonares. Métodos: No presente estudo, a reação em cadeia da polimerase (PCR) foi utilizada para a detecção do gene rhlR (codificação ramnolipídeo) de cepas isoladas. Foram realizados vários ensaios que garantiram seu comportamento virulento. 0 método de difusão em disco foi utilizado para verificar sua resistência a antibióticos. As estirpes isoladas foram resistentes a vários antibióticos aplicados. Resultado: Verificou-se que os homens são mais propensos a infecções respiratórias em comparação às mulheres. Membros do sexo masculino com idade entre 44 e 58 e 59 e 73 anos correm maior risco, enquanto mulheres com idade entre 44 e 58 anos também correm risco de infecções pulmonares. A resistência aos antibióticos foi observada medindo a zona de inibição nas cepas GCU-SG-M4, GCU-SG-M3, GCU-SG-M5, GCUSG-M2, GCU-SG-M1 e GCU-SG-M6. O GCU-SG-M2 foi resistente ao fluconazol (FLU), claritromicina (CLR), cefixima (CFM) e penicilina (P10). Nenhuma zona de inibição foi observada. Mas se notou uma zona difusa incomum ao redor dos discos antibióticos Ak e MEM. Os genes rhl R e 16s rRNA foram caracterizados e analisados. Conclusão: As conclusões do presente estudo ajudariam a aumentar a conscientização sobre a resistência a antibióticos de P.
\end{abstract}

*e-mail: nazipak@hotmail.com

Received: February 20, 2020 - Accepted: June 27, 2020

This is an Open Access article distributed under the terms of the Creative Commons Attribution License, which permits unrestricted use, distribution, and reproduction in any medium, provided the original work is properly cited. 
aeruginosa e, também, a sequência do gene rhl R pode ser usada como sequência de diagnóstico para identificar a sequência virulenta do gene rhl $\mathrm{R}$ das amostras quando isoladas do escarro de pacientes com pneumonia.

Palavras-chave: caracterização molecular, fatores de risco, resistência a antibióticos, ensaios de virulência.

\section{Introduction}

Pseudomonas aeruginosa bacterium is living in versatile environments. It is gram negative bacterium, metabolically able to regulate its systems and highly resistance to antibiotics causing it to spread in diverse habitats mainly in hospitals. P. aeruginosa is a human adaptable pathogen causing acute infections (bacteremia, pneumonia and urinary tract infections) in individuals with HIV infections, surgical wounds, cancer, carrying catheters or burns, or an organ transplantations (Gellatly and Hancock, 2013). The heterogeneous bacterial population of $P$. aeruginosa showed distinct microenvironments for biofilms (Ren et al., 2016). Metabolically active cell are at periphery and consume most of the oxygen, causing oxygen gradients in the biofilm (Su et al., 2016).

$P$. aeruginosa has vast ecological distribution with ability to fit in changed circumstances making it a successful opportunistic pathogen. According to American surveillance data, it is the third most common opportunistic pathogen. Pseudomonas aeruginosa releases hemolysins i.e. rhamnolipid as well as phospholipase-C that have very toxic consequences to the host cells and is responsible for the spread of pathogen throughout the target tissue. Both toxins act together for the catalysis to lipids and as well as lecithin. Structure of the rhamnolipid to some extent is similar to that of detergents. These rhamnolipids readily dissolve the phospholipids which are then easily cleaved by the action of phospholipase-C. Lung surfactants as a result are lost which initiate atelectasis that ultimately then leads towards chronic infections of lungs (Liu, 1966; Wardlaw et al., 2006). $P$. aeruginosa's exposure to the respiratory epithelial cells of human can result into the inhibition of mucociliary transportation and several ciliary actions (Read et al., 1992; Bhutta, 2007). Two Quorum sensing systems i.e. las QS and $r h l R$ are present in this bacterium. rhlR QS releases many toxins including rhamnosyl transferase and rhamnolipid Both toxins ultimately cause lung infection. A number of scientific projects had worked on the determination of rhamnolipids functioning which is still not clear. Firstly, they were known as surfactants because they have ability to reduce the surface tension (Smyth and Openshaw, 2006). Their study became very important because the hydrocarbons e.g. alkanes were firstly solubilized by them and then their uptake is promoted (Beal and Betts, 2000). They also have the property to enhance the hydrophobic ends of a cell surface that promotes the decomposition of the molecules that previously were slightly soluble. However, the purpose of the rhamnolipid is not just to assimilate the substrates which are not soluble that is evident by their competent growth on the substrates that were soluble (Al-Tahhan et al., 2000). A number of virulent agents are produced by the $P$. aeruginosa and for the transformation of these factors it has a highly developed mechanism through which bacterial density is checked and these cells communicate with each other through signals. Once the bacterial biofilm has been formed it enables the pathogen to detect any change in its environment, and it can respond in a very appropriate manner after the processing of information received. Additional activities that have recently been observed these are thought to be (Gray, 1997). Aims and objectives of the current study included screening of Pseudomonas aeruginosa involved in acute pulmonary infections. Also to determine the virulence of Pseudomonas aeruginosa via detection the rhlR gene of Pseudomonas aeruginosa associated with acute pulmonary infections in humans.

\section{Materials and Methods}

\subsection{Sample Collection}

Blood samples, sputum samples and samples of lower respiratory tract pneumonic patients were provided from a running project in GCU Microbiology laboratory. Among these samples secretions of lower respiratory tract had been obtained by endotracheal suction catheter (nelton). Pediatric mucus extractor had been used for the samples from bronchoscopy whereas blood culture vials (TSB with SPS aerobic) were being used for blood samples (Figure 1).

\subsection{Isolation and characterization of Pseudomonas aeruginosa}

Bacterial isolation from sputum samples of pneumonic patients was done using citrimide agar medium (Figure 2). Pure culture was obtained by spread plate method and streaking method. Initial confirmation of $P$. aeruginosa was made by morphological and biochemical test (Figure 3 ) (Tables 1 and 2).

\subsection{Molecular characterization of Pseudomonas aeruginosa and detection of rhlR gene}

PCR based confirmation of isolated strains of $P$. aeruginosa was carried out using universal primers for 16srRNA. Marcogen genomics was used to manufacture universal primers and gene specific primers.

\section{Results}

Percentile of the pulmonary infections caused by Pseudomonas aeruginosa was determined. These infections include respiratory failure Type-I and Type-II, Septicemia, Asthma, pulmonary edema, pneumothorax and chest filial injury. According to the resulted percentile pneumonia can be declared as most common pulmonary infection in patients, and septicemia \& Type-II respiratory failure as the $2^{\text {nd }}$ most common pulmonary infection.

\subsection{ETT v/s Blood Culture and Bronchoscopy}

Percentage of gram negative bacterial content $(P$. aeruginosa) in three different cultures was compared 


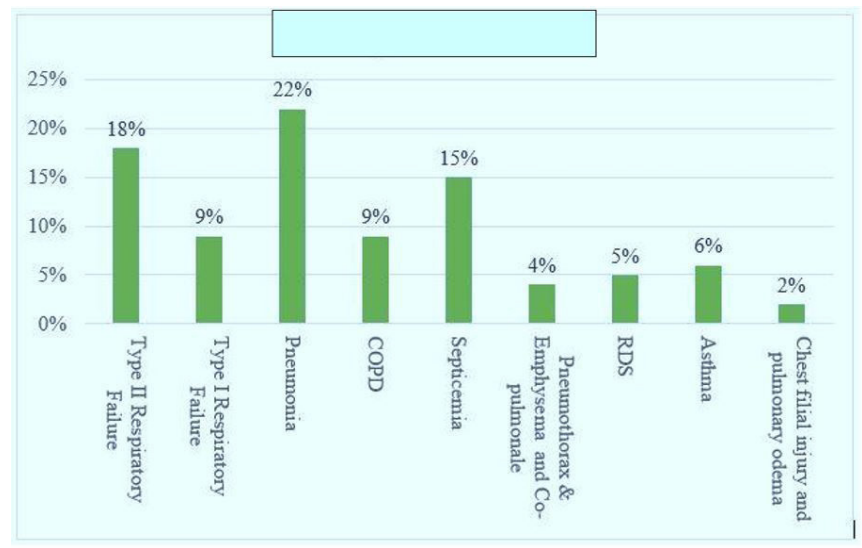

Figure 1. Showing Bar Graph of Pulmonary Infection Percentile of P. aeruginosa.

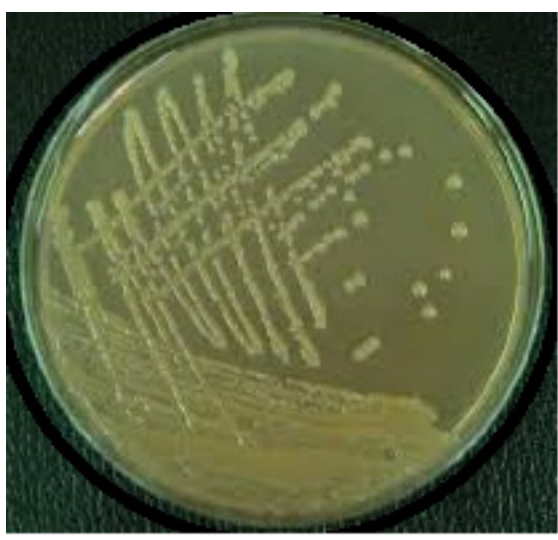

Figure 2. Showing P. aeruginosa Growth on Citrimide Agar Plates.

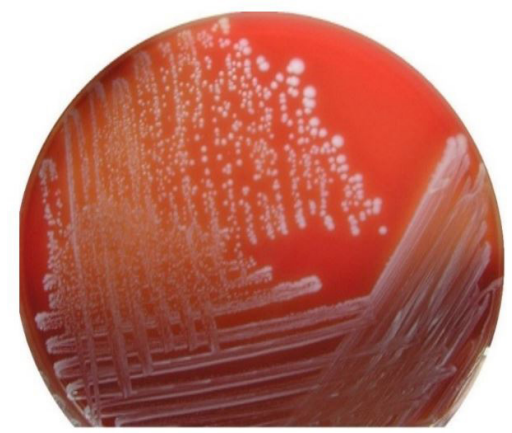

Figure 3. Showing $\beta$-Hemolysis by P. aeruginosa in Blood Agar Test.

with each other. Among all 57.7\% (26/45) the highest observed value was in ETT-culture $24.4 \%$ (11/45) on the other hand cocci the gram positive bacterial content was observed higher in blood culture $76 \%$ (34/45) than in the ETT culture 42\% (19/45). Similarly in bronchoscopy culture their higher percentage was observed 8/15 (53.3\%).

\subsection{Prevalence and Isolation of $P$. aeruginosa}

Sample collection in the present study has shown that in males (60\%) the rate of pulmonary infection is comparatively higher than females (40\%). Male members within the age of 44-58 and 59-73 are at a higher risk. In addition to that some females within the age ranging from 44-58 are also at a risk of getting pulmonary infections. Citrimide agar medium is a selective bacterial medium that only allows the growth of $P$. aeruginosa. Using this media

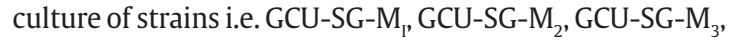
GCU-SG-M ${ }_{4}$, GCU-SG-M ${ }_{5}$, GCU-SG-M $\mathrm{M}_{6}$ were obtained.

\subsection{Virulence Behavior assays \\ i. Blood Agar Test: \\ Strains showed beta hemolysis \\ ii. Protease Test:}

The result of this activity was clearly observed by the presence of a hollow zone. Different strains provided different values and it is obvious that the sensitivity of each strain varies. These values were recorded as $9.5 \mathrm{~mm}$, $2.5 \mathrm{~mm}, 9 \mathrm{~mm}, 4 \mathrm{~mm}, 7 \mathrm{~mm}$, and $8 \mathrm{~mm}$ for GCU-SG-M GCU-SG-M $\mathrm{M}_{3}$ GCU-SG-M ${ }_{5}$, GCU-SG-M, GCU-SG-M and GCU-SG-M $\mathrm{M}_{6}$ respectively.

iii. Lipase and Lecithinase Test:

Results are shown in Figure 4.

iv. Biofilm-Formation Assay:

All strains produced positive results for this assay indicating the how virulent behavior these pathogenic bacterial strains have.

v. Pigment Production

a. Qualitative Assay:

Different culture media were used to determine the quality of pigment produced by the pathogenic strains. Among all strains the two i.e. GCU-SG-M 6 and GCU-SG-M were observed with a slight yellowish-green colored colonies that this is due to the production of pyoverdin pigment production (Figure 5). Remaining strains of P. aeruginosa probably produced another pigment i.e. Pyocyanin that's why these colonies appeared with bluegreen colored colonies on different agar media e.g. king A, king B, citrimide, LB and MH agar media (Table 3).

b. Quantitative Assay:

Quantitative of the produced pigment was measured by quantitative assay using spectrophotometer. Optical density was measured at OD $520 \mathrm{~nm}$. One by the pyocyanin producing strains i.e. GCU-SG-M $\mathrm{M}_{5}$ produced the highest value of optical density $(23 \mu \mathrm{g} / \mathrm{ml})$. The lowest pigment yielding strain that showed about $1.7 \mu \mathrm{g} / \mathrm{ml}$. 
Table 1. Showing results of different morphological tests.

\begin{tabular}{cccccccc}
\hline STRAINS & COLOR & ODOUR & SHAPE & SIZE & $\begin{array}{c}\text { SURFACE } \\
\text { ELEVATIONS }\end{array}$ & $\begin{array}{c}\text { SURFACE } \\
\text { EDGES }\end{array}$ & APPEARANCE \\
\hline GCU-SG-M & Dull Green & Fruity, grape like & spherical & Medium & Flat & Smooth & Semi transparent \\
GCU-SG-M & $\begin{array}{c}\text { Dark } \\
\text { green }\end{array}$ & Fruity, grape like & spherical & Large & Flat & Smooth & Translucent \\
GCU-SG-M & $\begin{array}{c}\text { Yellow } \\
\text { green }\end{array}$ & Fruity, grape like & spherical & Large & Flat & Rough & Translucent \\
GCU-SG-M & $\begin{array}{c}\text { Yellow } \\
\text { green }\end{array}$ & Fruity, grape like & spherical & Medium & Flat & Rough & Translucent \\
GCU-SG-M & $\begin{array}{c}\text { Yellow } \\
\text { green }\end{array}$ & Fruity, grape like & spherical & Small & Flat & Smooth & Translucent \\
GCU-SG-M & Yellow & Fruity, grape like & spherical & Large & Flat & Smooth & Translucent \\
\hline
\end{tabular}

Table 2. Showing results of different tests performed for biochemical characterization.

\begin{tabular}{lllllllllll}
\hline & CT & OX & CIT & UR & GLU & LAC & EMB & M.C & G.S & E.S.S \\
\hline GCU-SG-M & $* * *$ & $* * *$ & $* * *$ & $* * *$ & F & N.F & N.F Pinkish & N.F Colourless & -Ve rods & -Ve \\
GCU-SG-M & $* * *$ & $* * *$ & $* * *$ & $* * *$ & F & N.F & N.F Pinkish & N.F Colourless & - Ve rods & - Ve \\
GCU-SG-M & $* * *$ & $* * *$ & $* * *$ & $* * *$ & F & N.F & N.F Pinkish & N.F Colourless & - Ve rods & - Ve \\
GCU-SG-M & $* * *$ & $* * *$ & $* * *$ & $* * *$ & F & N.F & N.F Pinkish & N.F Colourless & - Ve rods & - Ve \\
GCU-SG-M & $* * *$ & $* * *$ & $* * *$ & $* * *$ & F & N.F & N.F Pinkish & N.F Colourless & - Ve rods & - -Ve \\
GCU-SG-M & $* * *$ & $* * *$ & $* * *$ & $* * *$ & F & N.F & N.F Pinkish & N.F Colourless & -Ve rods & - -Ve \\
\hline
\end{tabular}

Table 3. Showing results of qualitative assays.

\begin{tabular}{|c|c|c|c|c|}
\hline Strains & Citrimide Agar & EMB Agar & LB Broth & CLED Agar \\
\hline GCU-SG-M & B/G Pyocyanin & Pink colonies & Pyocyanin & Translucent colonies \\
\hline GCU-SG-M & B/G Pyocyanin & Pink colonies & Pyoverdin & Translucent colonies \\
\hline GCU-SG-M 3 & B/G Pyocyanin & Pink colonies & Pyocyanin & Translucent colonies \\
\hline GCU-SG-M 4 & Y/G Pyoverdin & Pink colonies & Pyocyanin & Translucent colonies \\
\hline GCU-SG-M 5 & B/G Pyocyanin & Pink colonies & Y/G Pyocyanin & Translucent colonies \\
\hline GCU-SG-M 6 & Y/G Pyoverdin & Pink colonies & Y/G Pyoverdin & Translucent colonies \\
\hline
\end{tabular}

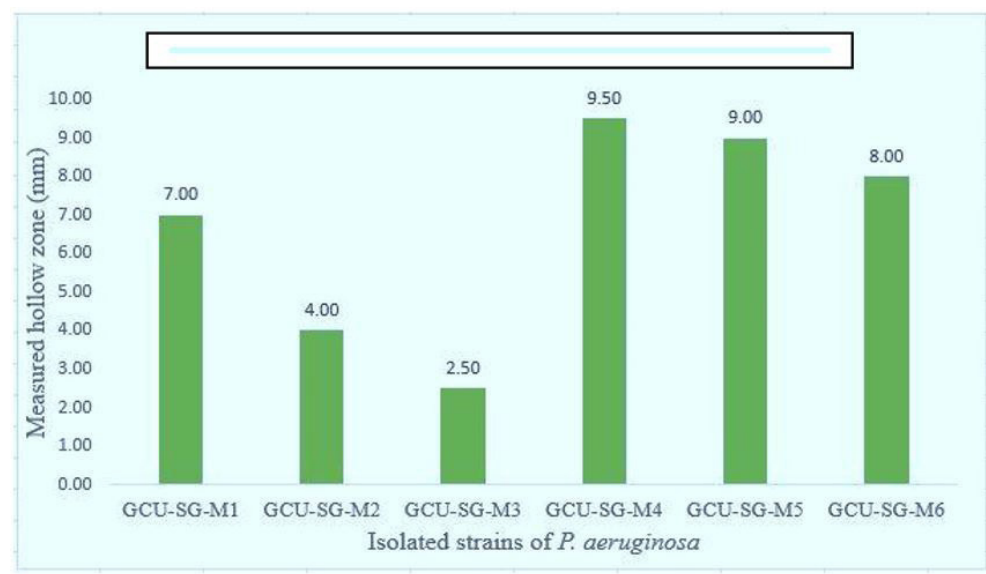

Figure 4. Bar graph showing proteolytic activity of isolated strains of $P$. aeruginosa. 


\subsection{Rhamnolipid Assay}

Strains which showed the maximum Rhamnolipid production resulted $2.4 \mu \mathrm{g} / \mathrm{ml}$ whereas, the minimum value obtained was $0.2 \mu \mathrm{g} / \mathrm{ml}$. Maximum Rhamnolipid yielding strains were those isolated from bronchoscopy samples as well (Table 4).

\subsection{Antibiotic Susceptibility Test}

GCU-SG-M $\mathrm{M}_{1}$ isolate was $100 \%$ resistant to the antibiotic disc of Amikacin AK, Fluconazole FLU, Meropenem MEM, Cefixime CFM, Clarithromycin CLR, and Penicillin PIG (Figure 6). GCU-SG-M $\mathrm{M}_{2}$ was $100 \%$ resistant to FLU, CLR, CFM and P10. No zone of inhibition was observed (Figure 7).

Table 4. Showing Results of Rhamnolipid Assay.

\begin{tabular}{ccc}
\hline Sr. No. & Sample name & $\begin{array}{c}\text { Rhamnolipid production } \\
(\mu \mathbf{g} / \mathbf{m l} \mathbf{l})\end{array}$ \\
\hline I & GCU-SG-M & 1.70 \\
II & GCU-SG-M & 2.01 \\
III & GCU-SG-M & 2.40 \\
IV & GCU-SG-M & 2.37 \\
V & GCU-SG-M & 0.25 \\
VI & GCU-SG-M & 1.96 \\
\hline
\end{tabular}

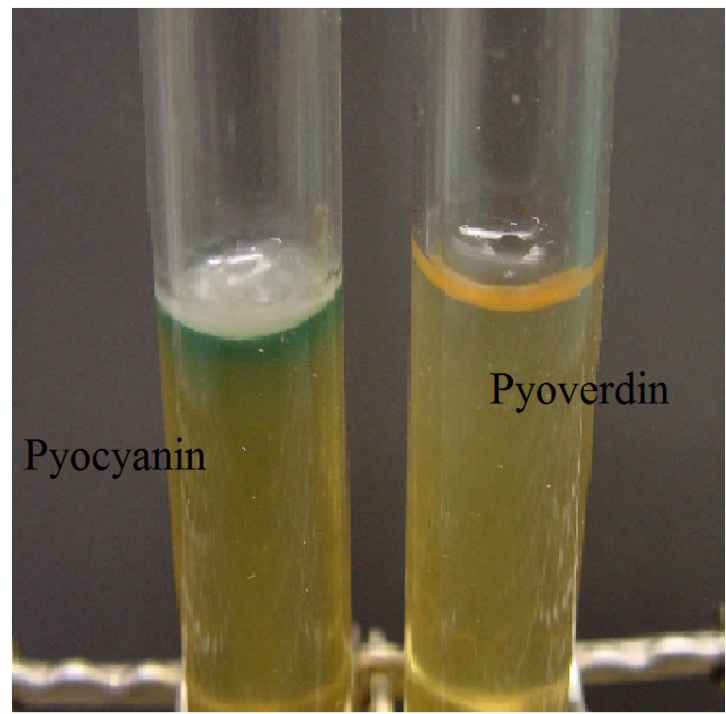

Figure 5. Shows production of Pyocyanin (Left) and Pyoverdin (Right) pigments in LB broth
But it showed unusual diffused zone around the Ak and MEM antibiotic discs (Tables 5 and 6).

\subsection{Fluorescence of $P$. aeruginosa Isolated under UV rays}

Fluorescence of the isolates was clearly observed which appeared as illuminating greenish light. This green light was considered as a confirmation for the present in fluorescent pigment present in the P. aeruginosa strains.

\subsection{Molecular Characterization}

Molecular identification with universal primers was done (Table 7) (Figures 8 and 9)

\subsubsection{Aligned sequence of $16 S$ rDNA of $P$. aeruginosa GCU-SG-M $M_{3}$}

CACGCTATCAGATGAGCCTAGGTCGGATTAGCTAGTTG GTGGGGTAAAGGCCTACCAAGGCGACGATCCGTAACTGG TCTGAGAGGATGATCAGTCACACTGGAACTGAGACACGGT CCAGACTCCTACGGGAGGCAGCAGTGGGGAATATTGGAC AATGGGCGAAAGCCTGATCCAGCCATGCCGCGTGTGTGA AGAAGGTCTTCGGATTGTAAAGCACTTTAAGTTGGGAGG AAGGGCAGTAAGTTAATACCTTGCTGTTTTGACGTTACCA ACAGAATAAGCACCGGCTAACTTCGTGCCAGCAGCCGCG GTAATACGAAGGGTGCAAGCGTTAATCGGAATTACTGGGC GTAAAGCGCGCGTAAGTGGTTCAGCAAGTTGGATGTGATC ACTACCAAGGCGACGATCCGTAACTGGTCTGAGAGGATGA TCAGTCACACTGGAACTGAGACACGGTCCAGACTCCTACG GGAGGCAGCAGTGGGGAATATTGGACAATGGGCGAAAGC CTGATCCAGCCATGCCGCGTGTGTGAAGAAGGTCTTCGGA TTGTAAAGCACTTTAAGTTGGGAGGAAGGGCAGTAAGTTA ATACCTTGCTGTTTTGACGTTACCAACAGAATAAGCACCGG CTAACTTCGTGCCAGCAGCC

\subsection{Amplification of the Targeted rhlR gene}

\subsubsection{Aligned rhlR gene sequence of $P$. aeruginosa GCU-SG-M3 (Figures 10 and 11)}

Aligned sequence of $P$. aeruginosa rhlR gene showed 99\% homology with previously reported rhlR gene sequences.

AGGAATGACGGAGGCTTTTTGCTGTGGTGGGACGGTTT GCGTAGCGAGATGCAGCCGATCCACGACAGCCAGGGCGT GTTCGCCGTCCTGGAAAAGGAAGTGCGGCGCCTGGGCTT CGATTACTACGCCTATGGCGTGCGCCACACGATTCCCTTCA CCCGGCCGAAGACCGAGGTCATGGCACCTATCCCAAGGCC TGGCTGGAGCGATACCAGATGCAGAACTACGGGGCCGTG GATCCGGCGATCCTCAACGGCCTGCGCTCCTCGGAAATGG

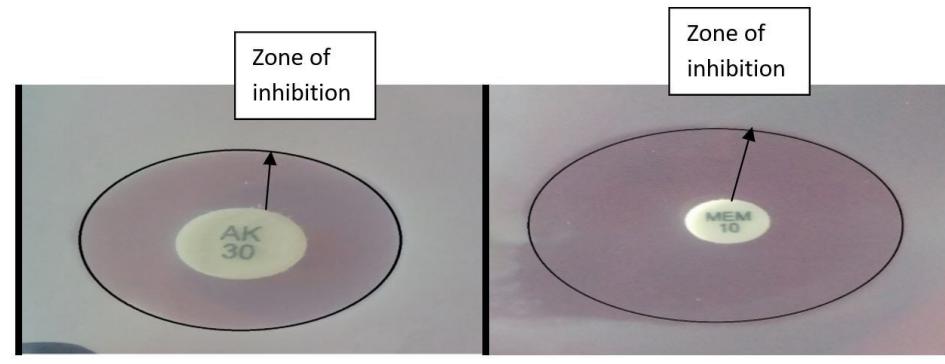

Figure 6. Inhibition zone around Amikacin (AK) and Meropenem MEM. 
Table 5. Results of Different Virulence Behavior Assays.

\begin{tabular}{cccccccc}
\hline Strains & Lip & Lec & Prot & Pyo & Rham & Bio & Hem \\
\hline GCU-SG-M & $+v e$ & $+v e$ & $+v e$ & Y/G & $+v e$ & $+v e$ & $\beta$ \\
GCU-SG-M & $+v e$ & $-v e$ & $-v e$ & Y/G & $+v e$ & $+v e$ & $\beta$ \\
GCU-SG-M & $+v e$ & $+v e$ & $+v e$ & B/G & $+v e$ & $+v e$ & $\beta$ \\
GCU-SG-M & $+v e$ & $-v e$ & $+v e$ & B/G & $+v e$ & $+v e$ & $\beta$ \\
GCU-SG-M $_{5}$ & $+v e$ & $+v e$ & $+v e$ & Y/G & $+v e$ & $+v e$ & $\beta$ \\
GCU-SG-M & $+v e$ & $+v e$ & $-v e$ & Y/G & $+v e$ & $+v e$ & $\beta$ \\
\hline
\end{tabular}

Note: Lip; Lipase Lec; Lecthinase Prot; Protease Pyo; Pyocyanin Rham; Rhamnolipid Hem; Hemolysis Mot; Motility Bio; Biofilm CR; Congo red assay B/G; Blue green $\mathbf{Y} / \mathbf{G}$; Yellow green.

Table 6. showing antibiotic discs used in disc diffusion method.

\begin{tabular}{cccc}
\hline Sr. No. & Name of antibiotic & Symbols & Potency \\
\hline I. & Fluconazole & FLU & $25 \mathrm{mcg}$ \\
II. & Clarithromycin & CLR & $15 \mathrm{mcg}$ \\
III. & Amikacin & AK & $30 \mathrm{mcg}$ \\
IV. & Cefixime & CFM & $5 \mathrm{mcg}$ \\
V. & Penicillin & PIG & $10 \mathrm{mcg}$ \\
VI. & Meropenem & MEM & $10 \mathrm{mcg}$ \\
\hline
\end{tabular}

Table 7. Universal primers for 16srRNA and Primers for rhamnolipid gene.

\begin{tabular}{cc}
\hline 1492R Sequence & 5'-GGCTACCTTGTTACGACTT -3' \\
27F Sequence & 5'-AGAGTTTGATCCTGGCTCAG-3' \\
Primers for rhamnolipid gene & \\
Oligo F Sequence & 5'-CTCCCCGGGCAACTCCAAAAG-3' \\
Oligo R Sequence & 5'-AATTTGCTCAGCGTGCTTTC-3' \\
\hline
\end{tabular}

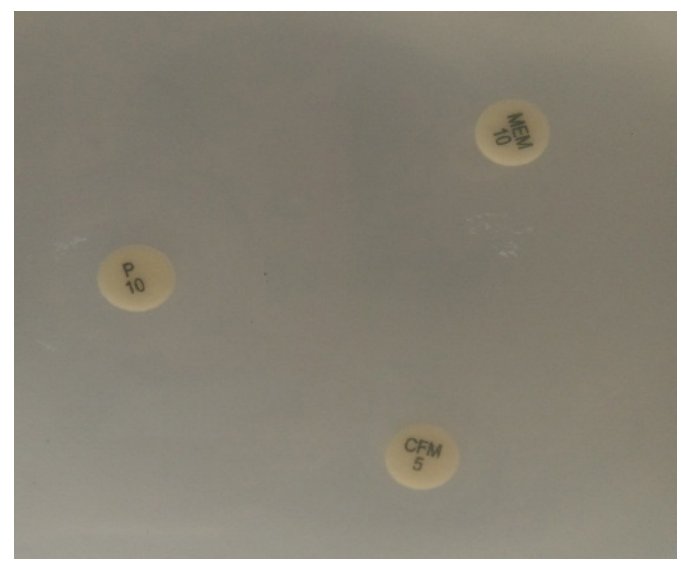

Figure 7. Resistance of $P$. aeruginosa having no inhibition zone around antibiotic disc

TGGTCTGGAGCGACAGCCTGTTCGACCAGAGCGGATGCTC TGGAACGAGGCTCGCGATTGGGGCCTCTGTGTCGGCGCG ACCCTGCCGATCCGCGCGCCGAACAATTTGCTCAGCGTGC TTTCCGTGGCGCGCGACCAGCAGAACATCTCCAGCTTCGA GCGCGAGGAAATCCGCCTGCGGCTGCGTTGCATGATCGAG TGCTGACCCAGAAGCTGACCGACCTGGAGCATCCGATGCT

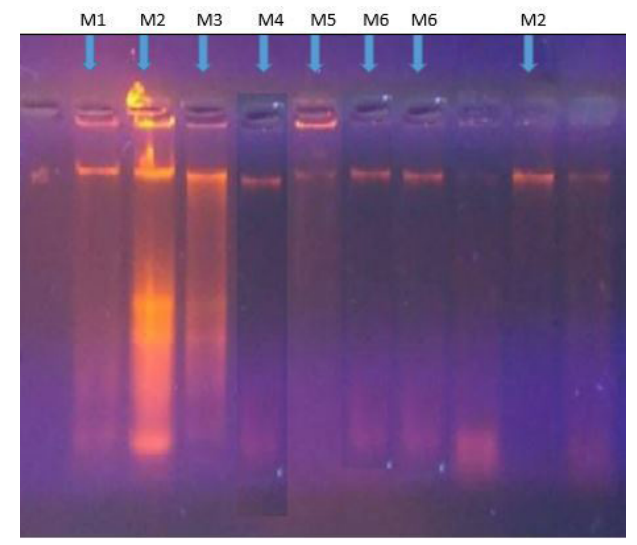

Figure 8. Showing bands of DNA under UV light in Gel Electrophoresis

GATGTCCAACCCGGTCTGCCTGAGCCATCGCGAACGCGAG ATCCTGCAATGGACCGCCGACGGCAAGAGCTCCGGGGAA ATCGCCATCATCCTGAGCATTTCCGAGAGCACGGTGAACT TCCACCACAAGAACATCCAGAAGAAGTTCGACGCGCCGAA CAAGACGCTGGCTGCCACCTACGCCGCGGCGCTGGGCCTC ATC 


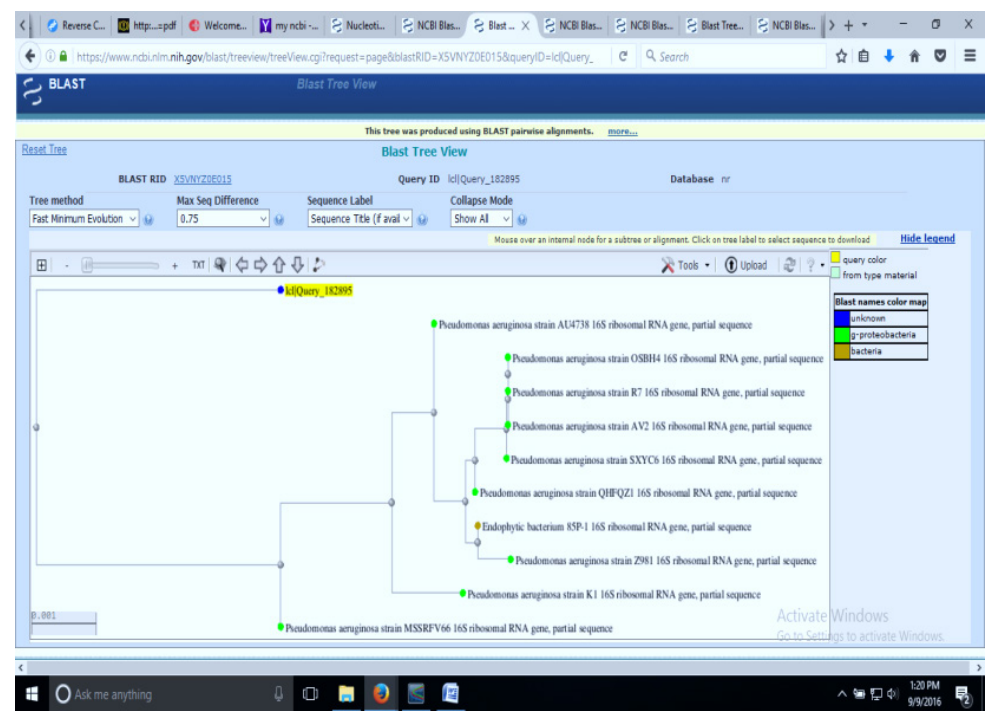

Figure 9. Dendrogram showing similarity of $P$. aeruginosa

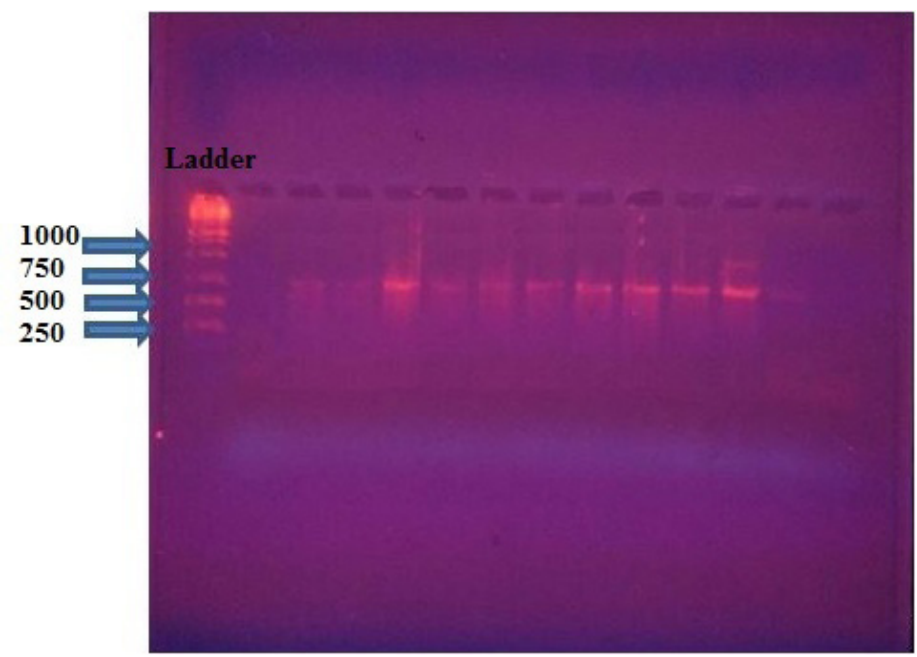

Figure 10. Bands glowing closer to the ladder band with $750 \mathrm{bp}$ are representing PCR products.

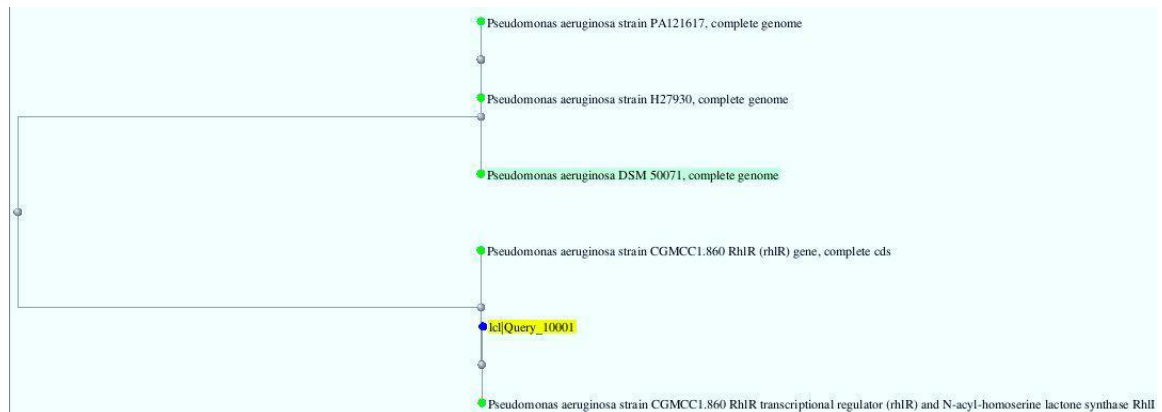

Figure 11. Showing dendrogram of P. aeruginosa GCU-SG-M

\section{Discussion}

Among all pathogenic bacteria the most common is $P$. aeruginosa that is responsible for $57.7 \%$ of VAP infections and $53.3 \%$ of cystic fibrosis is also caused by this pathogen. Our results are supported by the research work of Kumar et al. (2005) according to which the most common pathogenic bacteria is $P$. aeruginosa (63.5\%) which is followed by Staphylococcus aureus (33.3\%), Acinobacter lwoffi $(22.6 \%)$ in the spread of VAP infections. Similar results had been reported in different studies from other 
regions (Arora et al., 2011). Some of the previous studies have shown that the infection of $\mathrm{P}$. aeruginosa are more common in females than males. For example $48 \%$ of male individuals and $52 \%$ of the female individuals and effected according to Read et al. (1992). Similarly the research work of Khattak et al., 2013 have shown that females are at higher risk of infection (54\%) than in males (45\%). But in present study higher rate of infection is scene in the males (i.e. $60 \%$ ) but in females it is $40 \%$. These results are supported by the previous work of Rashid and Kornberg (2000) and Khattak et al. (2013) that show higher rate of susceptibility in male $(56 \%, 60 \%)$ respectively than in females (44\%, 40\%). This variation can be explained by the difference in climatic condition of various geographic regions of the world. Virulence behavior assays and antibiotic resistance to a wide range of antibiotics have shown that $P$. aeruginosa involved in hospital acquired pneumonia, ventilator acquired pneumonia is highly efficient multi drug resistant pathogenic bacteria. There are a number of genes that play important role in formation of $P$. aeruginosa biofilm (that contributes in its resistant nature), in the production of rhamnolipid as well as in synthesis of pyocyanin. Which are the virulent expressions of these genes in other words (Ochsner et al., 1994). There are undoubtedly number of these type of genes either involved in the reaction of autoinducers or in the secretion of virulent products. The results of all virulent assays of present study supports the results of previous studies of Lee et al. (2006) as P. aeruginosa have showed positive results of all virulence assessing assay (Ali et al., 2015). Our findings would help in raising awareness about antibiotic resistance of $P$. aeruginosa associated with pulmonary infections in patients. Arasu et al. (2016) reported that there was a $70.7 \%$ susceptibility of $P$. aeruginosa isolates to Meropenem but also concluded Ciprofloxacin was the most active agent ( $85.4 \%$ susceptibility) against $P$. aeruginosa strains along with Amikacin (95.1\% susceptibility).

\section{Acknowledgement}

Highly thankful to GC University for providing research facilities to carry out research work.

\section{References}

AL-TAHHAN, R.A., SANDRIN, T.R., BODOUR, A.A. and MAIER, R.M., 2000. Rhamnolipid-induced removal of lipopolysaccharide from Pseudomonas aeruginosa: effect on cell surface properties and interaction with hydrophobic substrates. Applied and Environmental Microbiology, vol.66, no. 8, pp. 3262-3268. http:// dx.doi.org/10.1128/AEM.66.8.3262-3268.2000. PMid:10919779.

ALI, Z., MUMTAZ, N., NAZ, S.A., JABEEN, N. and SHAFIQUE, M., 2015. Multi-drug resistant Pseudomonas aeruginos: A threat of nosocomial infections in tertiary care hospitals. JPMA, vol. 65, no. 12, pp. 12-16.

ARASU, A., BABCOCK, B., BABU, S., CIESLEWICZ, J., DATAR, M., ITO, K., MOTWANI, R., SRIVASTAVA, U. and WIDOM, J. 2016. Stream: The stanford data stream management system. In M. GAROFALAKIS, J. GEHRKE and R. RASTOGI. Data Stream
Management. Berlin, Heidelberg: Springer. pp. 317-336. http:// dx.doi.org/10.1007/978-3-540-28608-0_16.

ARORA, S., LUND, C., MOTWANI, R., SUDAN, M. and SZEGEDY, M., 2011. Proof verification and the hardness of approximation problems. Journal of the Association for Computing Machinery, vol. 45, no. 3, pp. 501-555. http://dx.doi.org/10.1145/278298.278306.

BEAL, R. and BETTS, W., 2000. Role of rhamnolipid biosurfactants in the uptake and mineralization hexadecane in Pseudomonas aeruginosa. Journal of Applied Microbiology, vol. 89, no. 1, pp. 158-168. http://dx.doi.org/10.1046/j.1365-2672.2000.01104.x. PMid: 10945793.

BHUTTA, Z.A., 2007. Dealing with childhood pneumonia in developing countries: how can we make a difference? Archives of Disease in Childhood, vol. 92, no. 4, pp. 286-288. http://dx.doi. org/10.1136/adc.2006.111849. PMid:17376934.

GRAY, K.M., 1997. Intercellular communication and group behaviour in bacteria. Trends in Microbiology, vol. 5, no. 5, pp. 184-188. http://dx.doi.org/10.1016/S0966-842X(97)01002-0. PMid:9160506.

GELLATLY, S.L. and HANCOCK, R.E., 2013. Pseudomonas aeruginosa: new insights into pathogenesis and host defenses. Pathogens and Disease, vol. 67, no. 3, pp. 159-173. http://dx.doi. org/10.1111/2049-632X.12033. PMid:23620179.

KHATTAK, M., ISHAQ, M., GUL, M., HUSSAIN, M.M., ALI, G., MOHAMMAD, A., JAVED, K. and PARVEZ, A., 2013. Isolation and identification of pseudomonas aeruginosa from ear samples and its antibiogram analysis. KJMS, vol. 6, no. 2, pp. 234-236.

KUMAR, R.S., AYYADURAI, N., PANDIARAJA, P., REDDY, A., VENKATESWARLU, Y., PRAKASH, O. and SAKTHIVEL, N., 2005. Characterization of antifungal metabolite produced by a new strain Pseudomonas aeruginosa PUPa3 that exhibits broad spectrum antifungal activity and biofertilizing traits. Journal of Applied Microbiology, vol. 98, no. 1, pp. 145-154. http:// dx.doi.org/10.1111/j.1365-2672.2004.02435.x. PMid:15610427.

LEE, J.H., LEQUETTE, Y. and GREENBERG, E.P., 2006. Activity of purified QscR, a Pseudomonas aeruginosa orphan quorum-sensing transcription factor. Molecular Microbiology, vol. 59, no. 2, pp. 602-609. http://dx.doi.org/10.1111/j.1365-2958.2005.04960.x. PMid: 16390453.

LIU, P.V., 1966. The roles of various fractions of Pseudomonas aeruginosa in its pathogenesis: II. Effects of lecithinase and protease. The Journal of Infectious Diseases, vol. 116, no. 1, pp. 112116. http://dx.doi.org/10.1093/infdis/116.1.112. PMid:4956054.

OCHSNER, U.A., FIECHTER, A. and REISER, J., 1994. Isolation, characterization, and expression in Escherichia coli of the Pseudomonas aeruginosa rhlAB genes encoding a rhamnosyltransferase involved in rhamnolipid biosurfactant synthesis. The Journal of Biological Chemistry, vol. 269, no. 31, pp. 19787-19795. http://dx.doi.org/10.1016/S0021-9258(17)320896. PMid:8051059.

RASHID, M.H. and KORNBERG, A. 2000. Inorganic polyphosphate is needed for swimming, swarming, and twitching motilities of Pseudomonas aeruginosa. Proceedings of the National Academy of Sciences, vol. 97, no. 9, pp. 4885-4890. http://dx.doi.org/10.1073/ pnas.060030097.

REN, X., LIU, J., REN, J., MENG, X., FANG, Z. and TANG, F., 2016. Fluorescent Ag nanoprobes for the highly selective detection of mercury (II) ions and colorimetric detection of hydrogen peroxide. Journal of Nanoscience and Nanotechnology, vol. 16, no. 7, pp. 6719-6725. http://dx.doi.org/10.1166/jnn.2016.11326.

READ, R.C., ROBERTS, P., MUNRO, N., RUTMAN, A., HASTIE, A., SHRYOCK, T., HALL, R., MCDONALD-GIBSON, W., LUND, V., TAYLOR, G. and ET., 1992. Effect of Pseudomonas aeruginosa 
rhamnolipids on mucociliary transport and ciliary beating. Journal of Applied Physiology, vol. 72, no. 6, pp. 2271-2277. http://dx.doi.org/10.1152/jappl.1992.72.6.2271. PMid:1629083.

SMYTH, R.L. and OPENSHAW, P.J., 2006. Bronchiolitis. Lancet, vol. 368, no. 9532, pp. 312-322. http://dx.doi.org/10.1016/S01406736(06)69077-6. PMid:16860701.

WARDLAW, T., SALAMA, P., JOHANSSON, E.W. and MASON, E., 2006. Pneumonia: the leading killer of children. Lancet, vol.
368, no. 9541, pp. 1048-1050. http://dx.doi.org/10.1016/S01406736(06)69334-3. PMid:16997649.

SU, W., TANG, J., DONG, L., MA, L., HUANG, Z., LIU, Z. and LIU, J., 2016. Preparation and synergistic antibacterial effects of poly (ethyleneimine) stabilized silver antibacterial agents for light colored fabrics. Nanoscience and Nanotechnology Letters, vol. 8, no. 6, pp. 471-477. http://dx.doi.org/10.1166/ nnl.2016.2161. 